\title{
Nutrient composition of Allanblackia Paviflora seed kernels and oil compared with some plant fats and oils and application of the oil in soap preparation
}

\author{
Joseph Adubofuor ${ }^{1 *}$, Wilfred Sefah ${ }^{2}$ and James Henry Oldham ${ }^{3}$ \\ ${ }^{1}$ Department of Food Science and Technology, Kwame Nkrumah University of Science and Technology, Kumasi, \\ Ghana. \\ ${ }^{2}$ Department of Hotel, Catering and Institutional Management, Kumasi Polytechnic, Kumasi, Ghana. \\ ${ }^{3}$ Department of Biochemistry and Biotechnology, Kwame Nkrumah University of Science and Technology, Kumasi, \\ Ghana.
}

Accepted 13 February, 2013

\begin{abstract}
The Allanblackia tree is found in parts of West, Central and East Africa and grows primarily in tropical rainforests. The oil from the seeds has been used by local communities but not on a commercial scale. The study was conducted to determine the nutrient composition of Allanblackia paviflora seeds and compare with some plant fats as well as assess the use of the oil in soap preparation. The oil was extracted by a screw press and also by solvent extraction using petroleum ether. The proximate composition showed that the dried seed kernels have a high fat content of $67.59 \%$, low protein and ash contents of 4.27 and $1.98 \%$, respectively. The major minerals in the seeds were potassium and phosphorus. The predominant fatty acids in the extracted oils were stearic acid and oleic acid with contents of about 52 and $45 \%$ respectively and the lowest amount was palmitic acid. The extremely high stearic acid content and very low palmitic acid content distinguished Allanblackia oil from palm and palm kernel oils. Sensory evaluation of soap samples prepared from the oil indicated that the soap had good lathering ability and washing efficiency.
\end{abstract}

Key words: Allanblackia paviflora, nutrient composition, plant fats and oils, sensory evaluation.

\section{INTRODUCTION}

Allanblackia belongs to the Guttiferae family, subfamily Clusiodeae and is a non-timber forest product (NTFP) which can be found as wild and undomesticated tree species in the rainforests of African countries such as Nigeria, Kenya, Congo, Angola, Cameroon, Tanzania, Uganda and Ghana (http://www.absinitiative.info/uploads/media/Addis_0909_Muchugi_01.pdf;

Bürkle and Palenberg, 2009).

Allanblackia is an evergreen forest tree confined to tropical Africa, to a height of $30 \mathrm{~m}$ tall. Allanblackia trees of which there are only nine similar species, occur from Sierra Leone to Tanzania. Most attention is currently

*Corresponding author. E-mail: jadubofuor@gmail.com. Tel: +249622839 . focused on Allanblackia paviflora (Upper Guinea and, Ghana westwards), Alanblackia floribunda (from Benin and Nigeria east to eastern DR Congo and Angola), Allanblackia stuhlmannii and Allanblackia ulugurensis which occur in East Africa in the mountains of Eastern Tanzania. The tree is common in the wild and is frequently used as a shade tree for cocoa. A. parviflora is sometimes considered a synonym of $A$. floribunda. However, their areas of distribution are disjunct. The two species are very similar, but $A$. floribunda can be distinguished by the folded disk glands of the male flowers and longer pedicel. The fats from the seeds of $A$. floribunda and $A$. stuhlmannii are very similar in comparison to that of A. parviflora. A. Parviflora is an oilrich tree crop that can also be used as shade tree and for medicinal purposes. They are mostly found in the wild forests in the Western, Ashanti and Eastern regions of 
Ghana (Ofori et al., 2008; Orwa and Oyen, 2007; Stucki, 2005).

In Ghana and from the uplands of the Eastern Arc Mountains in Tanzania to the lowlands of Sierra Leone in West Africa, the oil-rich seeds of the Allanblackia tree have been harvested by local communities for generations for food, to make cooking oil, and in more recent times for soap, similar to Elaeis palm oil, but have not been used on a commercial scale. Allanblackia oil has a higher melting point and in cooking it can congeal before the food is eaten. Originally collected mainly from the wild, the domestication of this tree and increased demand for the oil is an opportunity to boost incomes for African farmers. The increase in demand has come from potential uses of the oil identified by the international company Unilever for use in food products like spreads; vegetable based dairy products and ice cream. The seeds are valued because of the highly nutritive oil which can be used in the food and cosmetic industries (Buss and Tissari, 2010; Bürkle and Palenberg, 2009). Seeds and fruits are edible. The seeds yield vegetable fat while the bitter seedcake is used as an animal feed (Orwa et al., 2009). The seed oil of $A$. paviflora is of prime importance as a foreign exchange earner and is being developed as a rural based enterprise in many African countries notably Ghana, Nigeria, Cameroon and Tanzania (Shrestha and Akangaamkum, 2008).

Allanblackia oil is very similar to current oils in that it consists of familiar triglycerides in commonly used vegetable oils. It contains minor constituents like tocopherol and has good storage stability. The oil can also be mixed with other fats and oils to modify physical properties. Its composition and relatively high melting point makes the fat a valuable raw material that can be used without transformation to improve the consistency of margarines, cocoa butter substitutes and similar products. On a commercial scale, the use of the oil has been at a low level. In most parts of Africa, the traditional use has decreased over the last 50 years and been in favour of other liquid oils. Nevertheless, Allanblackia has been identified by FAO as a crop of high potential interest to the development of rural communities and the seed oil has the potential to become a new profitable and sustainable raw material which could be recognized internationally (http://www.allanblackiaghana.com/pages/FAG.html).

The objectives of this research work was to determine the nutrient composition of Allanblackia seed oil and compare with some plant fats and also to assess the use of the oil in soap preparation.

\section{MATERIALS AND METHODS}

\section{Source and preparation of $\boldsymbol{A}$. paviflora seeds}

The seeds of $A$. paviflora used for the study were manually removed from the fruits obtained from a village in New-Edubease in the Ashanti Region of Ghana. Twenty kilograms $(20 \mathrm{~kg})$ of the seeds were washed and sun dried for three days. The seeds were then stored in polyethylene bags under room temperature for two weeks after which they were dehulled and milled for the analyses. Figures 1 and 2 shows the whole dried dehulled and milled seed kernels of $A$. paviflora.

\section{Proximate analyses of Allanblackia Kernels}

The methods for the determination of the proximate composition of the kernels were based on AOAC (1990). Analyses were carried out in triplicates. Reagents were obtained from the Department of Biochemistry and Biotechnology and Department of Chemistry, KNUST.

\section{Determination of the mineral composition}

In the mineral analyses, $2 \mathrm{~g}$ of the dried sample was ashed in a muffle furnace at $600^{\circ} \mathrm{C}$ for $2 \mathrm{~h}$. The ash was then dissolved in 10 $\mathrm{ml}$ of $5 \mathrm{M} \mathrm{HCl}$. The dissolved sample was filtered into a $50 \mathrm{ml}$ volumetric flask and diluted to the $50 \mathrm{ml}$ mark. The sample was then directly analyzed for the minerals. Using the Atomic Absorption Spectrophotometer (AAS) (Model: UNICAM 929AA Spectrophotometer, UK), the mineral analyzed were Sodium $(\mathrm{Na})$, Copper (Cu), Potassium (K), Calcium (Ca), Phosphorus (P) and Manganese (Mn) (James, 1995).

\section{Extraction of Allanblackia oil}

Two oil samples were extracted by mechanical and solvent extraction. The mechanical extracted oil (designated as SPO) by means of a screw press was based on the optimum conditions established by Sefah et al. (2010) by heating the sieved milled samples with a moisture content of $13 \%$ to a temperature of $100^{\circ} \mathrm{C}$ for 2 h. Figure 3 shows the manual screw press used for the mechanical extraction of the oil. Solvent extracted oil (SEO) was by means of the Soxhlet apparatus and extraction was carried out using petroleum ether as the solvent for $16 \mathrm{~h}$.

\section{Qualitative test of phytochemicals in the Allanblackia oil}

Terpenes and carotenoids were determined qualitatively by methods described by Asante (1993) and analyses on saponins and tannins were based on the method outlined by Harbone (1984).

\section{Fatty acid profile of Allanblackia oil}

\section{Preparation of fatty acid methyl esters}

$0.1 \mathrm{~g}$ of the oil was dissolved in $20 \mathrm{ml}$ of diethyl ether followed by the addition of $2 \mathrm{ml}$ of $2 \mathrm{M}$ methanolic $\mathrm{KOH}$. The mixture was well corked and then swirled for thorough mixing. It was then centrifuged for $15 \mathrm{~min}$ at $250 \mathrm{rpm}$ and aliquots of the organic layer were taken for analyses.

Gas chromatographic method was used for the determination of the fatty acids. The fatty acid analyses was carried out by using a Perkin Elmer, Autosystem XL, Gas Chromatogragh (USA) equipped with a flame ionization detector (FID), coupled to a Varian integrator and chart recorder. A column of diethylene glycol succinate (DEGS) of $15 \%$ packed on Chromosorb W-AN-I20 mesh was used. The flow rate of the carrier gas, $\mathrm{N}_{2}$, was $22.6 \mathrm{ml} / \mathrm{min}$. and the F.I.D. hydrogen flow rate was $300 \mathrm{ml} / \mathrm{min}$. The GC was set on attenuation 4 , column temperature of $160^{\circ} \mathrm{C}$ and detector temperature of $200^{\circ} \mathrm{C}$. Volume injected was $1 \mu \mathrm{l}$. Identification and quantification of fatty acids were 


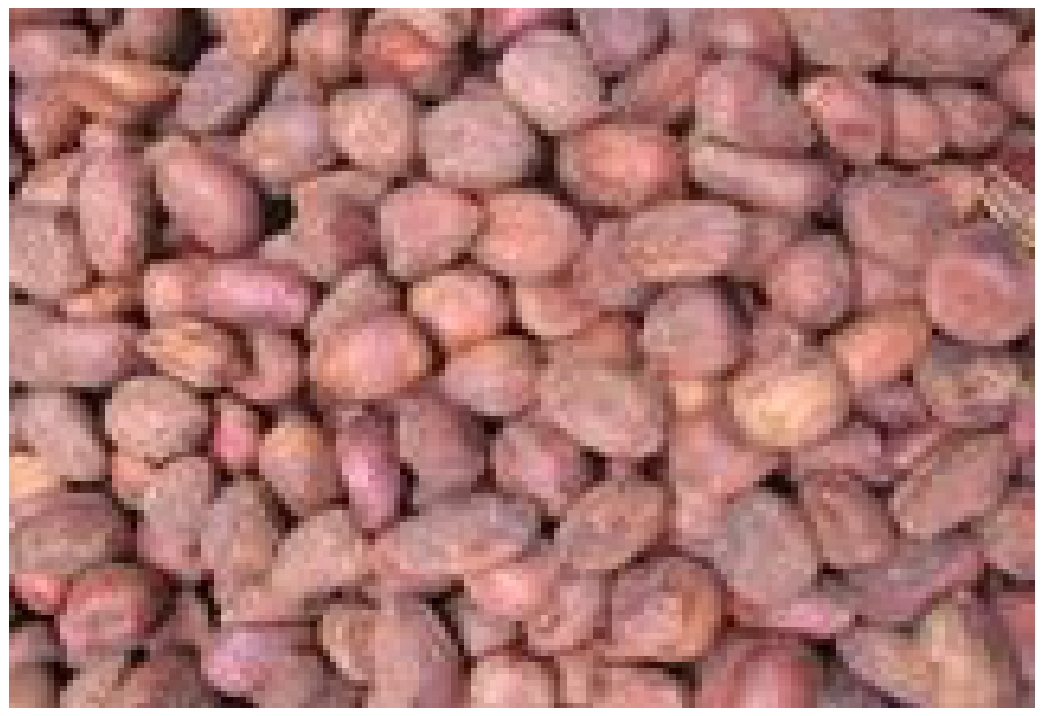

Figure 1. Dehulled seed kernels of Allanblackia parviflora.

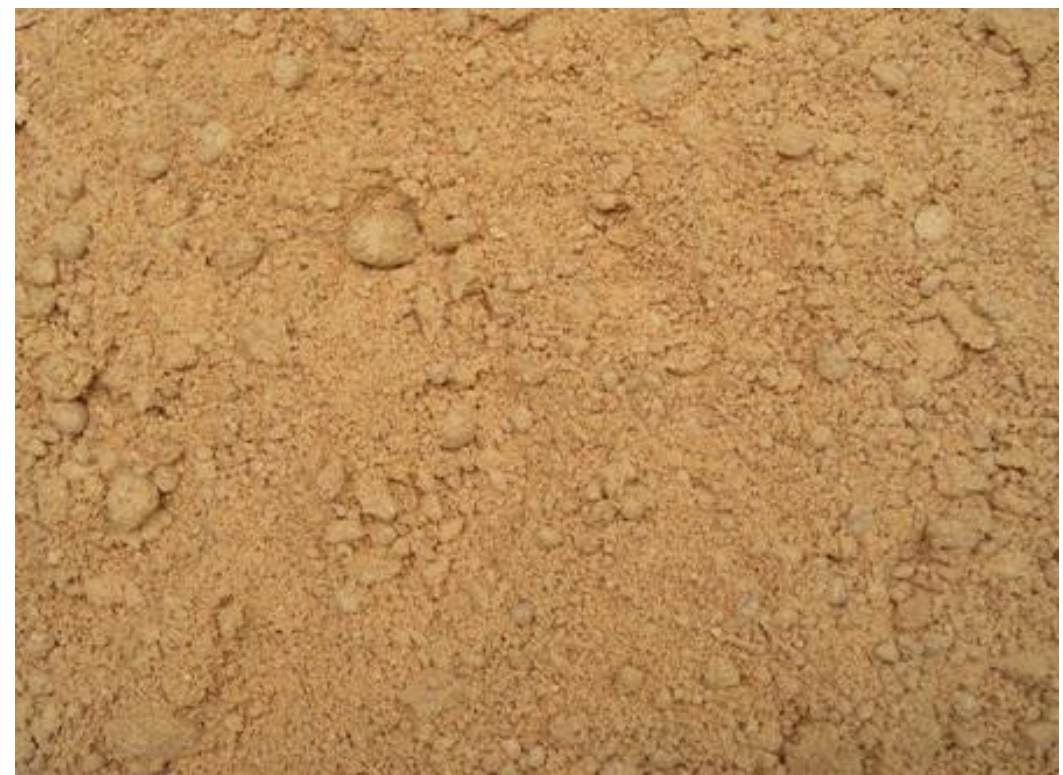

Figure 2. Milled A. paviflora seed kernels.

based mainly on direct comparison of the gas chromatogram response to available fatty acid methyl ester standards.

\section{Determination of the energy content}

The energy content of the kernels was determined by calculation based on Atwater factors by using $17 \mathrm{~kJ} / \mathrm{g}$ for protein and carbohydrate and $37 \mathrm{~kJ} / \mathrm{g}$ for fat.

\section{Preparation of soap from Allanblackia oil}

$100 \mathrm{~g}$ of the Allanblackia fat was weighed into a 1 litre beaker. The oil was then heated and saponification initiated by adding $20 \mathrm{ml}$ of
23.5\% $\mathrm{NaOH}$. Sixty (60.0) $\mathrm{g} \mathrm{NaOH}$ pellets was then added gradually while stirring until saponification was completed (the mixture was no longer oily). Eight grams of salt $(\mathrm{NaCl})$ in the form of saturated solution was then used to grain out the soap. The soap obtained was washed with water and filtered through a linen cloth. It was air-dried and a small amount of water was added to soften it whilst heating. The molten soap was then poured in casts and allowed to dry (Asante, 1993).

\section{Sensory evaluation prepared soap from Allanblackia oil}

The lathering ability, washing efficiency, colour, hardness and odour were physical properties determined by 53 panelists using a seven-point hedonic scale. The score was one (1) for very good 


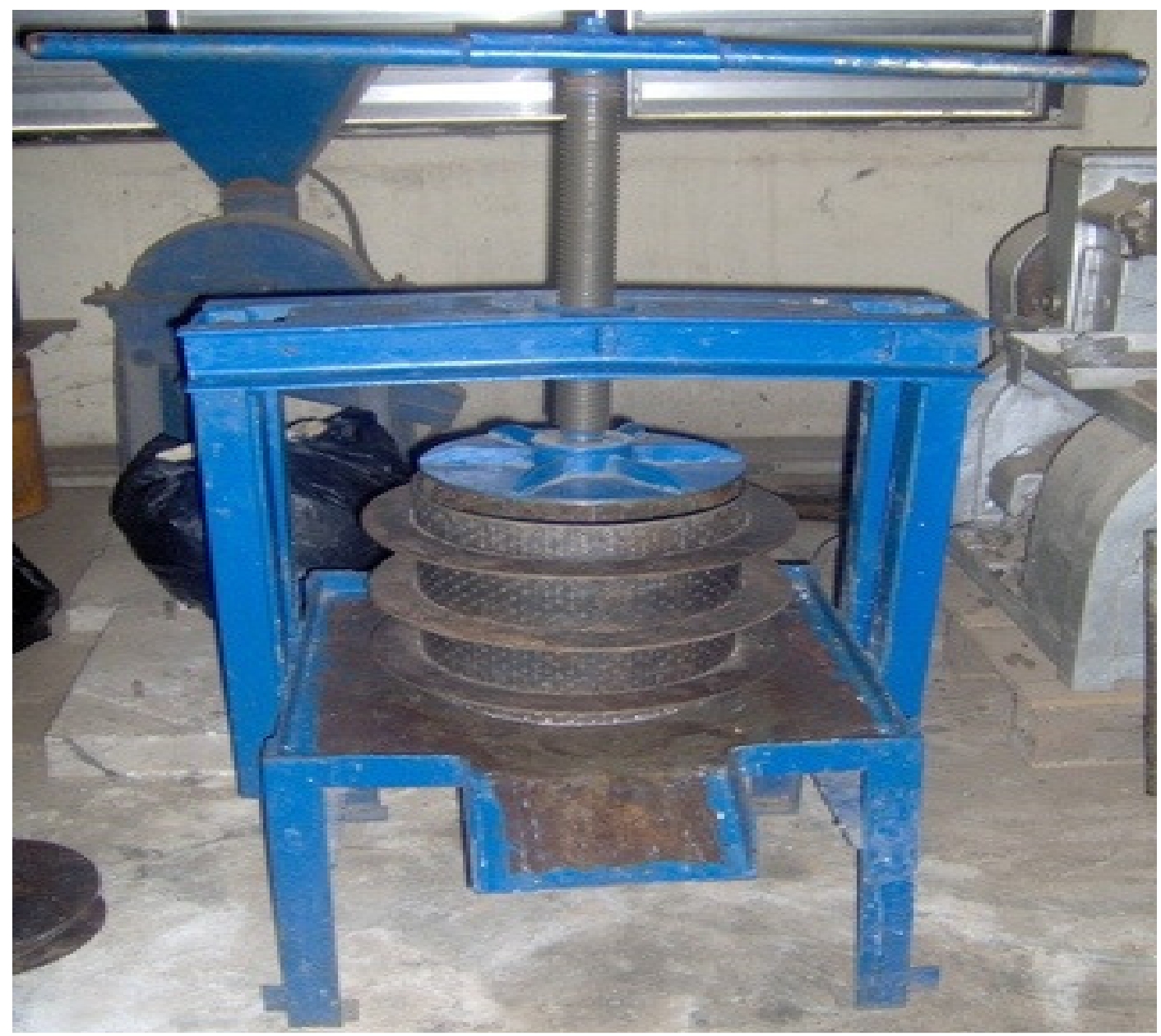

Figure 3. Manual screw press used for oil extraction.

and seven (7) for very bad. The colour was assessed by visual inspection whilst the odour was detected by smelling. The hardness was determined by pressing the soap in between the thumb and the third finger. Lather was formed by vigorously shaking the soap in about $200 \mathrm{ml}$ of water between 2 and $5 \mathrm{~min}$. The soap was used to wash an oil-stained cloth to measure its washing efficiency (Asante, 1993).

\section{Chemical properties of prepared soap from Allanblackia oil}

\section{Total fatty matter}

Five grams of the finished soap was dissolved in $30 \mathrm{ml}$ distilled water. The fatty acid was precipitated from the salt (neutral soap) present in the solution with $0.5 \mathrm{M} \mathrm{HCl}$. The solution was filtered and diethyl-ether was added to the precipitated fatty acid to aid drying. The dried fatty acid obtained was then weighed and the percentage fatty acid determined (Asante, 1993; Jolly, 1963).

\section{Free caustic alkali}

Five grams of a sample of the soap was weighed and dissolved in $30 \mathrm{ml}$ of $95 \%$ ethanol. A few drops of phenolphthalein indicator and $10 \mathrm{ml}$ of $20 \% \mathrm{BaCl}_{2}$ were added. The resulting solution was then titrated against $0.05 \mathrm{M} \mathrm{H}_{2} \mathrm{SO}_{4}$. The volume (v) of the acid obtained was multiplied by the factor 0.31 and divided by the weight of sample taken to obtain the percent $\mathrm{Na}_{2} \mathrm{O}$ present (Asante, 1993; Jolly, 1963).

\section{Statistical analyses}

The data obtained was subjected to statistical analyses using analysis of variance (ANOVA). Differences among the mean values were determined using Duncan's multiple range test.

\section{RESULTS AND DISCUSSION}

Table 1 shows the proximate composition and energy content of $A$. paviflora kernels compared with shea kernels and cocoa beans. The seeds contain a fat that is solid at ambient temperatures. The kernel, which makes up about 60 to $80 \%$ of the whole seed weight, contains about $72 \%$ fat. In some areas in Africa the seeds are eaten by children as a high-energy snack (Orwa et al., 2009; Orwa and Munjuga, 2007). Allanblackia kernels have comparatively very high content of fat and energy. 
Table 1. Proximate composition of Allanblackia seed kernels compared with cocoa and shea kernels.

\begin{tabular}{lccc}
\hline Component & Allanblackia & Shea kernels $^{\mathbf{1}}$ & Cocoa beans $^{\mathbf{2}}$ \\
\hline Moisture (\%) & $3.40 \pm 0.03$ & 3.3 & 5 \\
Fat (\%) & $67.59 \pm 0.02$ & 31.7 & 58 \\
Protein (\%) & $4.27 \pm 0.01$ & 7.7 & 13 \\
Ash (\%) & $1.98 \pm 0.11$ & 4.6 & 3 \\
Crude Fibre (\%) & $5.70 \pm 0.02$ & 6.2 & 10 \\
Carbohydrate (\%) & 17.06 & 46.6 & 11 \\
Energy (kJ/100 g) & $\mathbf{2 8 6 3 . 4 4}$ & $\mathbf{2 0 8 5 . 8 0}$ & $\mathbf{2 5 5 4}$ \\
\hline
\end{tabular}

Source: ${ }^{1}$ Ugese et al. (2010), ${ }^{2}$ Bockish (1993).

Table 2. Mineral content of Allanblackia seed and shea kernels $(\mathrm{mg} / \mathrm{kg})$.

\begin{tabular}{lcc}
\hline Type of mineral & Allanblackia & Shea kernels $^{\mathbf{2 a}}$ \\
\hline Sodium $(\mathrm{Na})$ & 5.24 & $12.17 \pm 0.83$ \\
Copper $(\mathrm{Cu})$ & 0.04 & - \\
Potassium $(\mathrm{K})$ & 8.41 & $1.55 \pm 0.03$ \\
Manganese $(\mathrm{Mn})$ & 0.13 & $4.15 \pm 0.78$ \\
Calcium $(\mathrm{Ca})$ & 0.10 & $0.28 \pm 0.343$ \\
Phosphorus $(\mathrm{P})$ & $\mathbf{8 . 3 4}$ & - \\
\hline
\end{tabular}

Source: ${ }^{2 a}$ Alhassan et al. (2011).

The seeds are comparatively low in protein, ash and fibre content. The results of six minerals analyzed and compared to shea kernels are shown in Table 2. With the exception of potassium, the minerals in shea kernels are higher than the amounts in Allanblackia kernels. The main minerals essential for human body include sodium, potassium, magnesium, calcium and phosphorus and these are required in amounts greater than $50 \mathrm{mg} /$ day. The values obtained for the main minerals were lower than the daily required amounts. The minimum daily requirement of potassium is estimated to be $782 \mathrm{mg}$. Trace elements such as manganese and copper are essential in concentrations of less than $50 \mathrm{mg} /$ day. The main and trace elements have varied functions in the body and play vital roles in metabolism and the functions of nerves, muscles and enzymatic systems in the human body. The concentration of copper was less than the maximum level of $0.4 \mathrm{mg} / \mathrm{kg}$ specified by Codex Allimentarius Commission. Copper is required in trace amounts and is poisonous at high concentrations. Manganese is an important component in a number of systems and is present in all living tissues. The concentration in the seed kernels was lower than the recommended daily intake of 2 to $5 \mathrm{mg}$ (Ronsivalli and Viera, 1992; Belitz et al., 2004; CODEX STAN 211 -1999)

Table 3 shows the results of qualitative tests of the presence of phytochemicals in the Allanblackia oil samples obtained by solvent extraction (SEO) and mechanical extraction (SPO) using the screw press.
Phytochemicals are naturally occurring, biologically active chemical compounds in plants which provide colour, aroma, flavour and also act as a natural defense system for host plants. Carotenoids are plant pigments which are responsible for colour (CFNI, 2005). Tannins contribute to taste in terms of bitterness and astringency. Terpenes impart pleasant smell and exhibit special pharmacological activities. Saponins have potent antifungal properties and have bitter taste (Ajayi et al., 2011; http://www.wileyvch.de/books/sample/3527317864_c01.pdf). The tests indicated the absence of carotenoids, terpenes, saponins and tannins in both samples. It could however be that some of these phytochemicals were present in very small quantities below detection by the methods used in the analyses.

\section{Fatty acid profile of Allanblackia oil and its comparison with other vegetable fats}

The fatty acid profile of Allanblackia oil and its comparison with other vegetable fats is shown in Tables 4 and 5. The Allanblackia seed oil is low in palmitic acid and is solid at room temperature. The fatty acid composition of stearic acid and oleic acid has been reported to range from 45 to 58 and 40 to $51 \%$ respectively (Orwa and Munjuga, 2007). The values obtained for the two samples in Table 3 fell within the reported ranges. In Table 5, which shows the average 
Table 3. Qualitative analyses of lipid soluble phytochemicals in Allanblackia oil.

\begin{tabular}{lllll}
\hline Sample & Carotenoids & Terpenes & Saponins & Tannins \\
\hline SPO & Absent & Absent & Absent & Absent \\
SEO & Absent & Absent & Absent & Absent \\
\hline
\end{tabular}

SPO, Screw-pressed oil; SEO, solvent extracted oil.

Table 4. Fatty acid characteristics of Allanblackia oil, borneo (tallow fat), shea butter and cocoa butter.

\begin{tabular}{lcccc}
\hline Fatty acids (\%) & Allanblackia & Shea Butter $^{4}$ & Cocoa Butter $^{3}$ & Borneo Tallow fat $^{3}$ \\
\hline Palmitic & 2.93 & 4 & 25 & 20 \\
Stearic & 52.25 & 42 & 37 & 42 \\
Oleic & 44.82 & 45 & 34 & 36 \\
\hline
\end{tabular}

Source: Belitz ${ }^{3}$ et al. (2004); ${ }^{4}$ Alander and Anderson (2002).

Table 6. Fatty acid characteristics of Allanblackia oil, palm oil and palm kernel oil.

\begin{tabular}{lccccc}
\hline Fatty acids (\%) & $\begin{array}{c}\text { Oleic acid } \\
\text { (C 18:1) }\end{array}$ & $\begin{array}{c}\text { Stearic acid } \\
\text { (C 18:0) }\end{array}$ & $\begin{array}{c}\text { Palmitic acid } \\
\text { (C 16:0) }\end{array}$ & $\begin{array}{c}\text { Myristic acid } \\
\text { (C 14:0) }\end{array}$ & $\begin{array}{c}\text { Lauric acid } \\
\text { (C 12:0) }\end{array}$ \\
\hline Allanblackia oil $^{4}$ & $40-51$ & $45-58$ & $0-2$ & $0-1$ & $0-1$ \\
Palm oil $^{2}$ & $26-52$ & $1-8$ & $32-59$ & $0-7$ & $0-2$ \\
Palm kernel oil $^{2}$ & $10-23$ & $1-3$ & $7-11$ & $14-20$ & $41-55$ \\
\hline
\end{tabular}

${ }^{2}$ Bockish (1993); ${ }^{4}$ EFSA (2007).

fatty acid compositions of both SEO and SPO, stearic acid content of Allanblackia is relatively higher than the other fats. The oleic acid composition compares very well with shea butter and is comparatively higher than the amounts found in cocoa butter and Borneo tallow fat. Cocoa butter and fats (solid at room temperature) belong to the oils and fats rich in palmitic and stearic acids with the latter referred to as cocoa butter substitutes (or cocoa butter interchangeable fats). They are relatively hard and can crystalline in several polymorphic forms. Their melting points are between 30 and $40^{\circ} \mathrm{C}$. When cocoa butter melts in the mouth a pleasant cooling sensation is experienced. This is characteristic of only a few types of triacylglycerols present in fats which contain predominantly palmitic, oleic and stearic acids. The fatty acid composition is also reflected by the resistance of these fats to auto-oxidation and microbiological deterioration. These fats are utilized preferentially in the manufacture of candy, chocolates and confections (Belitz et al., 2004). Although the major fatty acids represented in Table 4 show some degree of variation, the four plant fats are characterized by high levels of stearic and oleic acids and can similar be used together with cocoa butter as raw materials in the cosmetic and pharmaceutical industries.

Table 5 shows the fatty acid profile of $A$. paviflora oil, palm oil and palm kernel oil. The predominant fatty acids in Allanblackia oil being oleic acid and stearic acid are very high compared to the amounts found in palm oil and palm kernel oil. Allanblackia oil differs uniquely and distinctively from the other two oils by the extremely high stearic acid content ranging between 45 and $58 \%$ as against the respective amounts of 1 to 8 and 1 to $3 \%$ in palm oil and palm kernel oil, respectively.

Palmitic acid is the predominant saturated fatty acid in palm oil and in this sense, clearly distinguishes itself from the other two oils by the higher amounts of the fatty acids ranging from 32 to $59 \%$. Palm kernel oil also differs completely from the other two oils in terms of the relatively high percentage composition of myristic and lauric acids. Altogether the saturated fatty acid composition of palm kernel oil ranges between 55 and $75 \%$.

In terms of the monounsaturated fatty acid (MUFA), the three oils have considerable amounts with $A$. paviflora oil having the highest percentage composition of 40 to $51 \%$ followed by palm oil with a percentage composition of 26 to $52 \%$. Among the saturated fatty acids (SFAs), stearic acid is comparatively very high. Major food sources of stearic acid are meat, poultry, fish, grain products and milk/milk products. Fats rich in stearic acid include cocoa butter (typically consumed as chocolate), beef tallow, lard and butter (Kris-Etherton et al., 2005). Contrary to the perception that all SFAs are alike in terms of their cardiovascular disease risk, research demonstrates that 
Table 6. Percentage composition of triglycerides in Allanblackia oil, cocoa butter and shea butter.

\begin{tabular}{lcc}
\hline Type of fat & Tryglyceride fraction & Composition (\%) \\
\hline $\begin{array}{l}\text { Shear } \\
\text { butter }^{5}\end{array}$ & SOS & 40 \\
& SOO & 27 \\
Allanblackia & POS & 6 \\
oil $^{4}$ & SOS & 69.1 \\
& SOO & 23 \\
Cocoa & & \\
butter $^{6}$ & SOS & 26.4 \\
& POS & 42.1 \\
\hline
\end{tabular}

Source: ${ }^{5}$ Alander (2004), ${ }^{4}$ EFSA (2007), ${ }^{6}$ Lipp et al. (2001).

individual SFAs differ in their effects on blood cholesterol levels. Although it is classified as a saturated fatty acid, stearic acid is unique among the SFAs, in that investigations (in both human and animal studies) have consistently shown that stearic acid, unlike other long chain SFAs (those longer than 10 carbon chains) has no effect on blood total, LDL cholesterol (that is, 'bad' cholesterols) and high density lipoprotein (HDL) (that is, the 'good' cholesterol) cholesterol levels in adults. Unlike the other predominant long chain SFAs which are palmitic (C16:0), myristic (C14:0) and lauric (C12:0) acids (which increase blood cholesterol levels), stearic acid has been shown to have a neutral effect on blood total and low density lipoprotein cholesterol levels. This implies that this long chain SFA may not increase the risk for cardiovascular disease. Several possible explanations have been proposed to explain why stearic acid does not raise blood cholesterol levels and it has been a subject of considerable research. As to what biological mechanism(s) underlines stearic acid's regulation of cholesterol metabolism remains a question to be resolved (Kris-Etherton et al., 2005; Haumann, 1998; Grundy, 1994; Pearson, 1994; Mensink, 2005).

\section{Triglyceride fraction}

Table 6 shows the tryglyceride composition of Allanblackia oil, cocoa butter and shea butter. In shea butter the most common combinations of fatty acid is SOS (S-stearic, O-oleic) making up to $40 \%$ of the total trigylcerides followed by SOO $(27 \%)$ and POS (6\%) (Ppalmitic). The study of Di Vincenzo et al. (2005), found that SOO, OOO and SOS are the major triglycerides in shea butter with regional variation. The distinctive triglyceride composition of shea butter and Allanblackia dominated by SOS and SOO makes it easy to separate high melting stearin fraction from the low melting olein fraction by fractionation and the resultant stearin could be further used in the mixture with cocoa butter equivalents. Shea butter is highly regarded in the cosmetic field because of its high emolliency and moisturization capacities. The cosmetic and soap making industries can use shea butter to formulate cosmetics, soaps, shampoos, creams and balsams for hair and other skin cleansing and rejuvenating products (Alander, 2004). The similar characteristics of Allanblackia with shea butter, makes it potentially and comparably a useful raw material also in the cosmetic industry. Cocoa butter triglycerides are composed predominantly of POS, SOS and POP. Others include SOO and SLS (Lipp et al., 2001).

\section{Sensory evaluation and properties of Allanblackia soap}

The sensory properties of the Allanblackia soap samples evaluated by 53 panelists who used the soap to wash an oil-stained cloth are represented in Table 7. Figure 4 shows a sample of soap prepared from Allanblackia oil. The control sample used was Key bar soap, which is popularly sold in the market and usually used by many households for washing. There was no significant difference $(p>0.05)$ in the physical properties of the soap produced from the screw-pressed oil (SPO) and the solvent extracted oil (SEO) in terms of texture, lathering ability, washing efficiency and odour. Both soap samples showed good lathering ability and washing efficiency. The texture of both soap samples was found to be very hard and had a mild (that is, neither strong nor weak) odour).

Comparatively, the two soap samples produced from Allanblackia fat were harder than the Key bar soap but had similar washing efficiency. Also, there was a significant difference $(p<0.05)$ between Allanblackia soap and the Key bar soap in terms of lathering ability and odour. The lather formed from the Key bar soap was very good compared to the Allanblackia soap. In terms of overall acceptability, the Key bar soap was preferred compared to the Allanblackia soap. This might be due to its very good lathering ability, colour and odour. The Allanblackia soap samples were produced without addition of colourants and aroma inducing materials but due to the creamy colour of the soap produced from the screw-pressed oil, it was more preferred, compared to the soap produced from the solvent extracted oil.

The chemical properties of the soap samples were significantly different $(p<0.05)$. Comparatively, the solvent extracted fat had the highest total fatty matter and less moisture content than the screw-pressed oil. Both samples had no excess caustic alkali in the soap. The total fatty matter, free caustic alkali and moisture content of the soap prepared from all the two oil samples were found to satisfy regulations set by the Ghana Standards Authority.

\section{Conclusion}

A. paviflora kernels are high yielding oilseed which can 
Table 7. Physical and chemical properties of Allanblackia soap.

\begin{tabular}{llllll}
\hline \multirow{2}{*}{ Soap sample } & \multicolumn{5}{c}{ Physical properties } \\
\cline { 2 - 5 } & Texture & $\begin{array}{l}\text { Lathering } \\
\text { ability }\end{array}$ & $\begin{array}{l}\text { Washing } \\
\text { efficiency }\end{array}$ & Odour & Colour \\
\hline SPO & Very hard & Good & Good & Neither strong nor weak & Cream \\
SEO & Very hard & Good & Good & Neither strong nor weak & White \\
Key soap & Neither hard nor soft & Very good & Good & Strong & Pale Yellow
\end{tabular}

\begin{tabular}{cccc} 
& & Chemical properties & \\
Moisture (\%) & Total fatty matter $(\%)$ & Free caustic alkali \\
SPO & $27.70 \pm 0.13^{\mathrm{a}}$ & $59.96 \pm 0.02^{\mathrm{a}}$ & Below detection \\
SEO & $26.52 \pm 0.11^{\mathrm{b}}$ & $61.89 \pm 0.04^{\mathrm{b}}$ & Below detection \\
GSA & $<28$ & $>59$ & $<0.25$ \\
LSD & 1.094 & 0.522 & - \\
SED & 0.254 & 0.1213 & - \\
\hline
\end{tabular}

Values with different superscripts ( $a$ and $b)$ in the same column are significantly different $(p<0.05)$; LSD, least significant differences of means (at $5 \%$ ); SED, standard error of differences of means. GSA, Ghana Standards Authority.

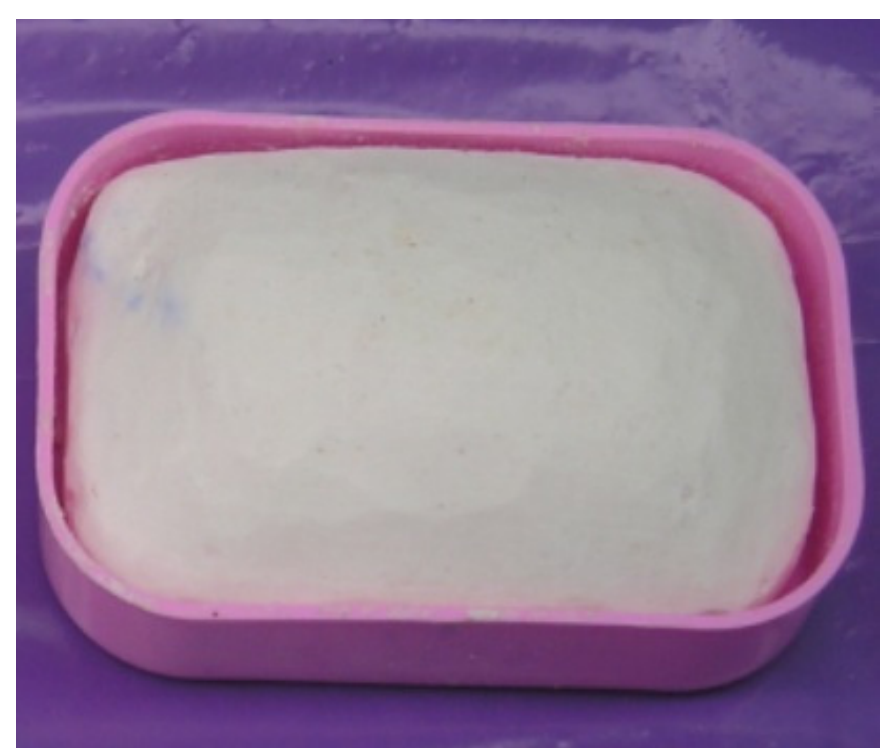

Figure 4. A prepared soap from Allanblackia oil.

serve commercially as a rich source of oil. Proximate composition showed a high fat content of $67.59 \%$ in $A$. paviflora kernels and low amounts of protein and minerals. Comparatively, the mineral content in Allanblackia are lower than the amounts in shea kernels. The fatty acid profile of solvent and screw-pressed oils indicated stearic acid and oleic acid as the predominant acids with contents of about 52 and $45 \%$ respectively. The extremely high stearic acid content and very low palmitic acid content distinguished Allanblackia from palm and palm kernel oils. The percentage composition of the triglycerides shows that $A$. paviflora can be used as an alternative vegetable oil to palm oil, cocoa butter and shea butter in the production of food and non-food products. Sensory evaluation of the properties of soap samples prepared from the oil indicated that the soap had good lathering ability and washing efficiency and was comparatively harder than Key soap which was used as the control sample. There was a significant difference $(\mathrm{p}<$ 0.05) between the Allanblackia soap and the Key Bar soap in terms of lathering ability and odour.

\section{REFERENCES}

Ajayi IA, Ajibade O, Oderinde RA (2011). Preliminary phytochemical analysis of some plants seeds. J. Chem Sci. 1(3):58-62

Alhassan E, Agbemava SE, Adoo NA, Agbodemegbe VY, Bansah CY, Della R, Appiah GI, Kombat EO, Nyarko BJB (2011). Determination of trace elements in Ghanaian shea butter and shea nuts by neutron activation analysis. Res. J. Appl. Sci. Eng. Technol. 3(1):22-25

Alander J (2004). Shea Butter- a Multi Functional Ingredient for Food and Cosmetics. Lipid Technol. 16:202-205.

Alander J, Andersson AC (2002). The Shea Butter Family - the Complete Emollient Range for Skin Care Formulations. Cosmetics and Toiletries Manufacture Worldwide 2002:28-32.

AOAC (1990) Official Methods of Analysis. $15^{\text {th }}$ Edition. Association of Official Analytical Chemists, AOAC Pub, Virginia, U.S.A. 69-84:951979

Asante FA (1993). The Chemistry of three indigenous seeds and their extraction, nutritional and industrial potentials of their oils. MPhil thesis. Department of Biochemistry, KNUST, Kumasi. pp. 42-73

Bockish J (1993). Handbook of Food Technology-Food fats and oils. Eugen Ulmer Limited and Co. p. 240

Buss C, Tissari J (2010). Allanblackia-an ingredient for poverty reduction

www.rural21.com/uploads/media/R21_Allanblackia_0310_01.pdf visited on November 12, 2012

Belitz HD, Grosch W, Schieberle P (2004). Food Chemistry third Edition, pp.427-431, 643, 651-652

Bürkle E, Palenberg M (2009). Allanblackia Supply chain as a Strategic Alliance with Unilever R\&D Netherlands. Global Public Policy Institute, GPPi. Pp. 19-20.

CODEX STAN 211-1999,

www.Codexallimentarius.org/input/.../standards/337/cxs_211e.pdf visited on December 03, 2012.

CFNI (2005). Phytochemicals. Carribean Food and Nutrition Institute, UWI Campus, st. Augustine Trinidad, W.I. 
http://www.paho.org/english/cfni/nyamnewsdec1-205.pdf

Di Vincenzo D, Maranz S, Serraiocco A, Vito R, Wiesman Z, Bianchi G (2005). Regional Variation in Shea Butter Lipid and Triterpene Composition in Four African Countries. J. Agric. Food Chem. 53:7473-7479.

European Food Safety Authority, EFSA (2007). EFSA J. 580:1-10

Grundy SM (1994). Influence of stearic acid on cholesterol metabolism relative to other long-chain fatty acids. Am. J. Clin. Nutr. 60:986-990.

Harbone JB (1984). Phytochemical Methods. A guide to modern techniques of plant analysis. $2^{\text {nd }}$ ed Chapman and Hall New York. pp. 120-126.

Haumann BF (1998). Stearic acid: a 'different' saturated fatty acid. INFORM (American Oil Chemists' Society) 9(3):202-208.

http://www.allanblackiaghana.com/pages/FAG.html).visited on July, 2011

http://www.abs-

initiative.info/uploads/media/Addis_0909_Muchugi_01.pdf, visted on February 01, 2013

http://www.wiley-vch.de/books/sample/3527317864_c01.pdf visited on December 03, 2012

James CS (1995). Analytical Chemistry of foods. Chapman and Hall.,Glasgow, UK 46:76-77.

Jolly SC (1963). Official Standardized and Recommended Methods of Analysis. Analytical methods committee, W. Heffer \& Son Ltd, Cambridge, pp. 144-148.

Kris-Etherton PM, Griel AE, Psota TL (2005). Dietary stearic acid and risk of cardiovascular disease: intake, sources, digestion, and absorption. Lipids 40:1193-1200,

Lipp M, Simoneau C, Ulberth F, Anklam E, Crews C, Brereton P, de Grey W, Schwack W, Wwiedmaier C (2001). Composition of Genuine Cocoa Butter and Cocoa Butter Equivalents. J Food Compos. Anal. 14:399-408

Mensink RP (2005). Effects of stearic acid on plasma lipid and lipoproteins in humans. Lipids 40:1201-1205,

Ofori DA, Peprah T, llenneh S, Bosompem, SA (2008) Allanblckia Domestication Project; Report on training workshop on vegetative propagation of Allanblckia parviflora, CSIR-Forestry Research Institute of Ghana, Kumasi 25th to 29th February, 2008.

Orwa C, Mutua A, Kindt R, Jamnadass R, Simons A (2009). Agroforest tree Database: a tree reference and selection guide version 4.0 (http://www.worldagroforestry.org/af/treedb/).
Orwa C, Munjuga M (2007). Allanblackia floribunda Oliv. In: van der Vossen, H.A.M. and Mkamilo, G.S. (Editors). PROTA 14: Vegetable oils/Oléagineux. [CD-Rom]. PROTA, Wageningen, Netherlands. Prota

Orwa C, Oyen LPA (2007). Allanblackia parviflora A.Chev. In: van der Vossen, H.A.M. \& Mkamilo, G.S. (Editors). PROTA 14: Vegetable oils/Oléagineux. [CD-Rom]. PROTA, Wageningen, NetherlandsPearson TA (1994). Stearic acid: a unique saturated fatty acid. Am. J. Clin. Nutr. 60(suppl):983-1072

Ronsivalli LJ, Viera ER (1992). Elementary food science $3^{\text {rd }}$ Edition, Van Nostrand Reinhold, NY. USA. pp. 26-27

Sefah W, Adubofuor J, Oldham JH (2010). Optimum conditions for expression of oil from Allanblackia floribunda seeds and assessing the quality and stability of pressed and solvent extracted oil. Afr. J. Food Sci. 4(9):563-570.

Shrestha RB, Akangaamlmm AD (2008). Novella partnership, a partnership for poverty reduction through sustainable enterprise development based on Allanblackia, SNV Ghana,Pp 20: In utility of grafting in tree domestication programme with special reference toallanjjlac/(fa parv/flora a. ciiev.D. A. Ofori; T. Peprah1; S Ilenneh JB. Yon Berg Z, Tchoundjeu R, Jamnadass 5 and AJ. Simons (2008) Gh. J. Forest. 23(24):42-48

Stucki V (2005). Allanblackia oil to boost rural income, The Forest conservation Programme, IUCN-The World Conservation Union, Rue Mauverney 28, Gland 1196, Switzerland. www.iucn.org/forest

Ugese FD, Baiyeri KP, Mbah BN (2010). Proximate traits of the seed and seed cake of shea buttertree (Vitellaria paradoxa C. F. Gaertn.) in Nigeria's savanna ecozone. J. Appl. Biosci. 31:1935-1941 